To cite this article: Seymen CM, Kaplanoglu I, Take Kaplanoglu G, Yazici GN, Erdogan D. The possible protective effects of curcumin in the case of benzo(a)pyrene administration on rat sperm motility and morphology. Ortadogu Tip Derg 2020; 12(2): 241-250. https://doi.org/10.21601/ortadogutipdergisi.723357

\title{
The possible protective effects of curcumin in the case of benzo(a)pyrene administration on rat sperm motility and morphology
}

\section{Benzo(a)piren uygulaması durumunda kurkuminin sıçan sperm motilitesi ve morfolojisi üzerine olası koruyucu etkileri}

\author{
Cemile Merve Seymen $^{1 *}$ (D), Iskender Kaplanoglu ${ }^{2}$ (D), Gulnur Take Kaplanoglu ${ }^{1}$ (D), \\ Gulce Naz Yazici ${ }^{3}$ (D), Deniz Erdogan ${ }^{1}$ (D) \\ ${ }^{1}$ Gazi University Faculty of Medicine, Department of Histology and Embryology, Ankara, Turkey \\ 2 Sağlık Bilimleri University, Etlik Zubeyde Hanim Women's Health Teaching and Research Hospital, Center of Assisted Reproduction, \\ Ankara, Turkey \\ ${ }^{3}$ Erzincan University Faculty of Medicine, Department of Histology and Embryology, Erzincan, Turkey \\ * Corresponding author: Cemile Merve Seymen E-mail: cmerveseymen@gmail.com ORCID: 0000-0002-8945-3801 \\ Received: 12 March 2020 Accepted: 15 April 2020
}

\begin{abstract}
Background: In this study, our aim is to investigate the possible protective effects of curcumin on potential damage caused by benzo(a)pyrene (BaP) on rat sperm motility and morphology.

Methods: 36 Wistar Albino male rats were divided into six groups: Group 1, Control; Group 2, Corn oil (BaP dissolver); Group 3, DMSO (Curcumin dissolver); Group 4, BaP; Group 5, Curcumin; Group 6, BaP+Curcumin. By the end of the six week oral administration period, left caudal epididymis and ductus deferens tissues were placed in Pure Sperm Wash (Nidacon) solution (at $37^{\circ} \mathrm{C}$ ) and dissected. Sperms were counted and stained. Measurements of the perinuclear ring of the manchette and the posterior portion of the nucleus were performed. All of the parameters were evaluated statistically.
\end{abstract}

Results: BaP administration caused a decrease in the number of total sperms and total motile sperms, while increasing abnormalities in tail, acrosome and cytoplasmic droplet particularly. Abnormalities did not approach the control group by curcumin administration in expected rates, but the percentage reduced. The number of total and motile sperms increased by curcumin. All parameters were statistically supported.

Conclusions: In conclusion, curcumin is one of the antioxidant that could be used potentially to inhibit the effects of Benzo(a)pyrene, but is ineffective in preventing all abnormalities.

Keywords: benzo(a)pyrene, curcumin, rat, sperm, morphology

() 2020 by the authors; licensee MEDITAGEM Ltd., Turkey. This article is an open access article distributed under the terms and conditions of the Creative Commons Attribution License (http://creativecommons.org/licenses/by/4.0/). 


\section{öz}

Amaç: Çalışmada, sıçan sperm hareketliliği ve morfolojisi üzerinde benzo(a)pyrene (BaP) uygulamasının neden olduğu potansiyel hasarlar üzerinde kurkuminin olası koruyucu etkilerinin incelenmesi amaçlanmıştır.

Yöntemler: 36 adet Wistar albino sıçan altı gruba ayrılmıştır: Grup 1, Kontrol; Grup 2, Mısır Yağı (BaP) çözücüsü; Grup 3, DMSO (kurkumin çözücüsü); Grup 4, BaP; Grup 5, Kurkumin; Grup 6, BaP+Kurkumin. Altı haftalık oral uygulama sonrasında deneklerin sol kaudal epididimis ve duktus deferens dokuları Pure Sperm Wash (Nidacon) solüsyonuna alınarak ( $37^{\circ} \mathrm{C}$ ) diseke edilerek sperm elde edildi. Spermler sayıldı ve boyandı. Manşetin perinükleer halkası ve nukleusun posterior parçası arası mesafe ölçülerek kaydedildi. Tüm veriler istatistiksel olarak analiz edildi.

Bulgular: BaP uygulaması sıçanlarda total sperm sayısı ile total hareketli sperm sayısında azalmaya; kuyruk ve akrozom anomalisi ile sitoplazmik droplet oranında ise artışa sebep olmuştur. Görülen anomalilerin kurkumin uygulaması ile beklenen oranlarda ve kontrol grubuna yaklaşacak şekilde düzelmediği ancak görülen anomali yüzdesinin azaldığı tespit edildi. Total sperm ve total hareketli sperm sayısının ise kurkumin uygulaması ile arttığı görüldü. Tüm veriler istatistiksel olarak da desteklendi.

Sonuç: Sonuç olarak kurkuminin bir antioksidan olarak, benzo(a)pyrene uygulamasının yol açtığı hasarlar üzerinde azalmaya yol açtığı ancak anomaliler üzerinde tamamen koruyucu olamadığı kanısına varıldı.

Anahtar kelimeler: benzo(a)pyrene, kurkumin, sıçan, sperm, morfoloji

\section{INTRODUCTION}

Environmental toxicants, especially hormonally active xenobiotics, have been identified as adversely affecting reproductive health in recent years [1,2]. Polycyclic aromatic hydrocarbons (PAHs) are a group of important vocational and environmental pollutants [3], formed during incomplete combustion of organic materials [4]. They have been found in air, water, food, and others [4]. PAHs become a significant environmental problem for humans and animals by affecting their health [5]. According to animal experiments, PAHs damage ovarian follicles, decrease the weights of reproductive organs, and cause infertility and abnormal fetal development [6], as well as being associated with the induction of paternally transmitted germ line mutations [7].

Benzo(a)pyrene (BaP) is a well-acknowledged member of the $\mathrm{PAH}$ group, and is released into the environment as a result of industrial emissions, forest fires, the manufacture of products such as tar, coke and aluminum, vehicle exhaust, oil spills from tankers, coal burning, wood fires and cigarette smoke [8]. It is known that $\mathrm{BaP}$ is a Group 1 carcinogen and has a toxic effect on reproduction according to animal models $[8,9]$. BaP exposure also shows its effects on male reproductive health $[10,11]$, and causes inhibition of spermatogenesis, decreased sperm production and motility, sperm cell apoptosis besides disrupting hormone profiles, such as reduced plasma testosterone and changing Leydig cell steroidogenesis [1,2]. Moreover, BaP induces oxidative stress, DNA damage and apoptosis in testicular tissue [1], and also inhibits the rate of DNA synthesis in spermatogenic cells among experimental animals through induction of oxidative stress [12]. In addition, it has been found that inhibition of DNA synthesis and other detrimental effects were prevented by treatment of animals with free radical scavengers [13].

Curcumin is one free radical scavenger [14] and a natural phytochemical derived from Curcuma longa; also known as turmeric [15]. According to a number of studies, curcumin is a potential therapeutic for many diseases, because of its anticarcinogenic, antioxidant, reno-protective, cardioprotective, neuroprotective [16], antimicrobial, immunomodulatory, anti-inflammatory properties and also it is effective on anti-Alzheimer's activities [17]. It shows these activities as strong antioxidant capacities that protect against oxidative damage in lipids, proteins, and DNA [18]. It has shown no toxicity in vitro in several cell culture systems, and in vivo in animal models and Phase I human clinical trials [16]. Additionally, the safety, tolerability, and non-toxicity of curcumin in high doses are well established by such human clinical trials [19]. In addition, it has been reported that curcumin protects the male reproductive tract against the damaging effects of oxidative stress [20]. According to the results of several studies, it is believed that curcumin may prevent peroxidative alteration in sperm and the testicular membrane which leads to the improvement of sperm 
motility and a decrease in sperm defects against various stressful conditions and reproductive damage [21]. Curcumin affects sperm functions as motility/capacitation and acrosome reaction/fertilization [17].

Therefore, the aim of this study is to investigate the possible protective effects of curcumin, as an antioxidant, on potential damage caused by benzo(a)pyrene ( $\mathrm{BaP})$, which is an important environmental pollution factor, on rat sperm motility and morphology.

\section{METHODS}

\section{Chemicals}

$\mathrm{BaP}$ and Curcumin were purchased from Sigma Chemical Co. (St Louis, MO, USA) and BaP was dissolved in corn oil by heating to obtain suitable concentrations for use. Curcumin was dissolved in DMSO (Sigma/Aldrich Chemical Co.). Fresh solutions were prepared daily and were stored in conical tubes at room temperature in darkness.

\section{Animals}

A total of thirty six Wistar albino male rats (Gazi University Medical School Experimental Animal Breeding and Experimental Research Center, Ankara, Turkey) were used in this research. Rats weighing 250 - $300 \mathrm{~g}$ were housed in clean, sterile, polypropylene cages under standard vivarium conditions (12 - hour light / dark cycle) with access to water and standard chow (Korkutelim Yem Ltd., Antalya, TURKEY) composing of $14 \%$ fat, $12 \%$ water, $25 \%$ protein, $7 \%$ cellulose, $8 \%$ total ash, $2 \%$ inorganic ash, $1 \% \mathrm{NaCl}, 1-1.8 \%$ calcium, $0.9 \%$ phosphore, $0.5-0.8 \%$ sodium, $1 \%$ lysine, and $0.3 \%$ methionine with adequate mineral and vitamin levels for the animals. The animals were housed one per cage in an airconditioned animal room at $22 \pm 3^{\circ} \mathrm{C}$ and $55 \pm 10 \%$ humidity. The animal experiments were premeditated and executed in accordance with ethical norms approved by Institutional Animal Ethics Committee Guidelines. The animals were acclimatized to laboratory conditions for seven days prior to the start of the experiments.

\section{Curcumin Preparation}

$0.6 \mathrm{~g}$ curcumin was dissolved in $15 \mathrm{ml} \mathrm{DMSO}$ and applied to the animals by gavage in $100 \mathrm{ml} / \mathrm{kg}$ / days dosage.

\section{BaP Preparation}

$0.06 \mathrm{~g} \mathrm{BaP}$ was dissolved in $15 \mathrm{ml}$ corn oil and applied to the animals by gavage in $10 \mathrm{ml} / \mathrm{kg}$ / days dosage.

\section{Experimental Design}

The rats were separated into six groups: Group 1, Control; Group 2, Corn oil (BaP dissolver 1ml / kg / days); Group 3, DMSO (Curcumin dissolver $1 \mathrm{ml} / \mathrm{kg} /$ days); Group 4, BaP (10 $\mathrm{ml} / \mathrm{kg} /$ days); Group 5, Curcumin (100 ml / kg / days); and Group 6, BaP + Curcumin (10 ml / kg / days + $100 \mathrm{ml} / \mathrm{kg} /$ days). They were applied by gavage at the same time every day for six weeks. At the end of the experiment, left caudal epididymis and ductus deferens tissues were collected under ketamine (45 mg / kg) and Xylazine (5 mg / kg) anesthesia.

\section{Preparation of the Sperms}

Left caudal epididymis and ductus deferens tissues were removed into Pure Sperm Wash (Nidacon) (at $37^{\circ} \mathrm{C}$ ) solution and dissected. Sperms were counted using a Makler Counting Chamber for spermiogram and stained with Spermac Stain (FertiPro) (Lot: FP12S05, Ref. No: SPS050) for morphological analysis. Perinuclear ring of the manchette and posterior portion of the nucleus measurements were performed. All of the parameters were evaluated statistically.

\section{Spermac Stain}

A thin feathered-edge smear of fresh, undiluted, and liquified semen sample was dried in air for five minutes. After this, the sample was fixed in formaldehyde solution for five minutes and washed in distilled water for $7 \times 1$ minutes. It was stained for two minutes in Stain A. When introducing the slide into the stain solution, the slide was slowly dipped seven times (about one dip per second) in and out of the stain. After that the sample was washed in distilled water for $7 \times 2$ minutes. The same procedure was performed for Stain $B$ and $C$. At the end of the staining procedure, the sample was observed under a Photo-light microscope (DM4000B Image Analyze System, Leica, Germany) and a Leica DFC280 plus camera (1000x) using oil immersion.

Acrosome $=$ dark green, nucleus $=$ stained red, equatorial region $=$ pale green, midpiece and tail = green .

\section{Statistical Analyses}

All of the parameters were analyzed using the Statistical Data Package for Social Sciences (SPSS) version of the 19.0 Software (SPSS Inc., Chicago, IL) program. All data was presented as Mean \pm Standard Deviation (SD). The differences between the groups were analyzed by Levene statistic test, Duncan statistic test and ANOVA tests. 


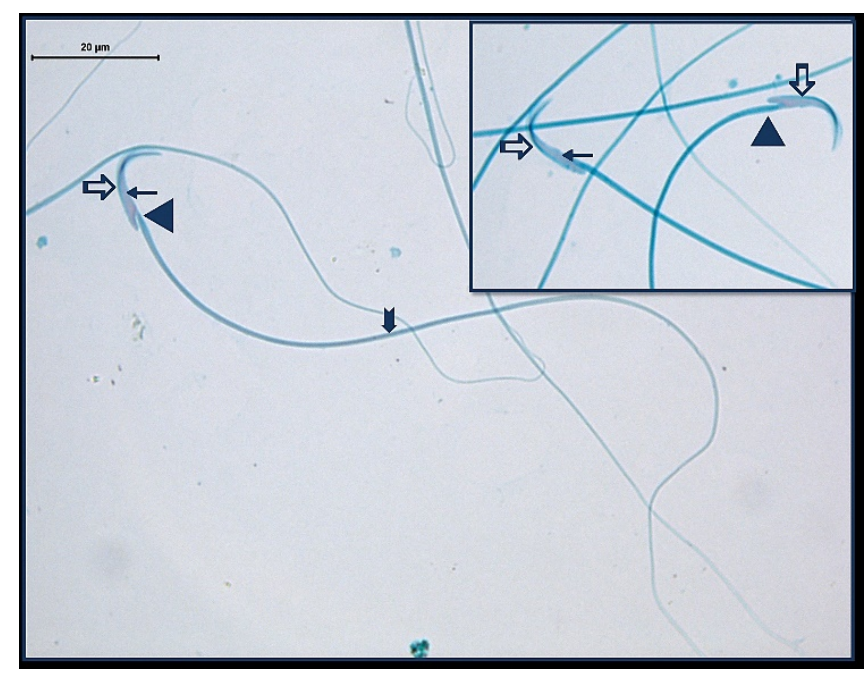

Figure 1. Normal sperms structure. Nucleus $(\rightarrow)$, acrosome $(\Rightarrow)$, neck $(\triangleright)$ and tail $(\Rightarrow)$ (Spermac $\times 1000)$

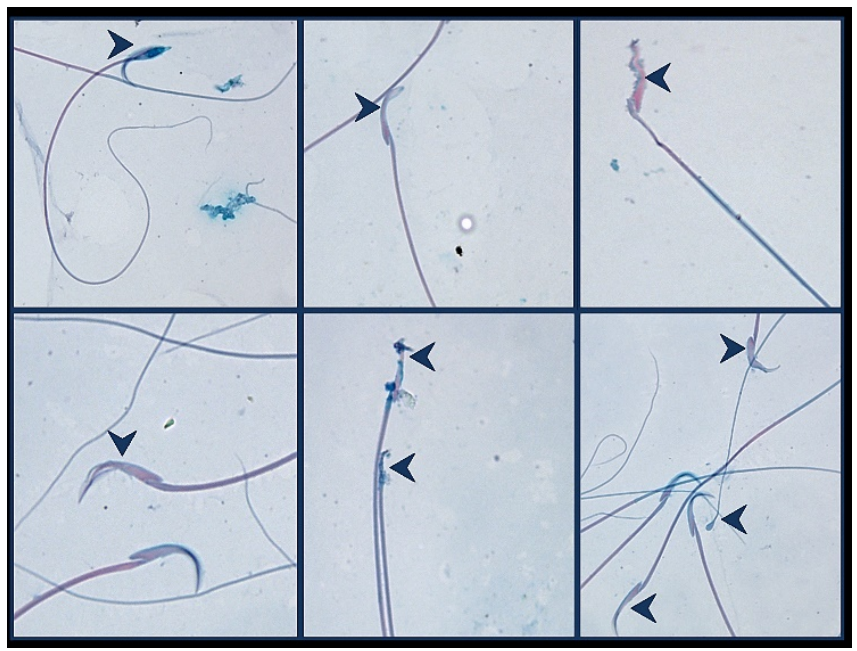

Figure 2. Sperms with head-structure abnormalities (>) (Spermac $\mathrm{x}$ 1000)

\section{RESULTS}

\section{Spermac Stain Results}

After sperm-smears were stained by Spermac stain, normalstructure sperms were seen with hook-shaped heads, convex-located acrosomes, central-located nuclei, normal neck structures and tails get thinner forward last pieces (Figure 1). Some sperms exhibited abnormalities at different rates for different groups. These abnormalities are classified as head, neck, acrosome, tail and cytoplasmic droplet. Different abnormal shapes of the hook-shaped head structures were seen as abnormal heads of sperms, and pinhead sperms were also revealed from place to place (Figure 2). The neck abnormalities were found mostly as bending or as thickening of the neck (Figure 3). Rupturing of the distal part, and bending or thinning of the middle part in some segments were seen by examination of tail abnormalities (Figure 4). The acrosome abnormalities were

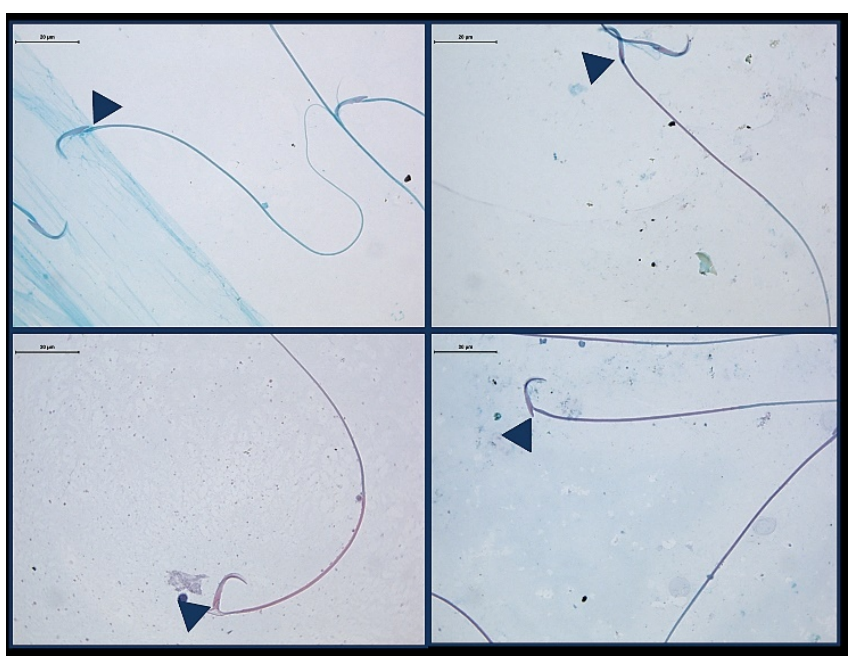

Figure 3. Sperms with neck-structure abnormalities. Neck ( (Spermac x1000)

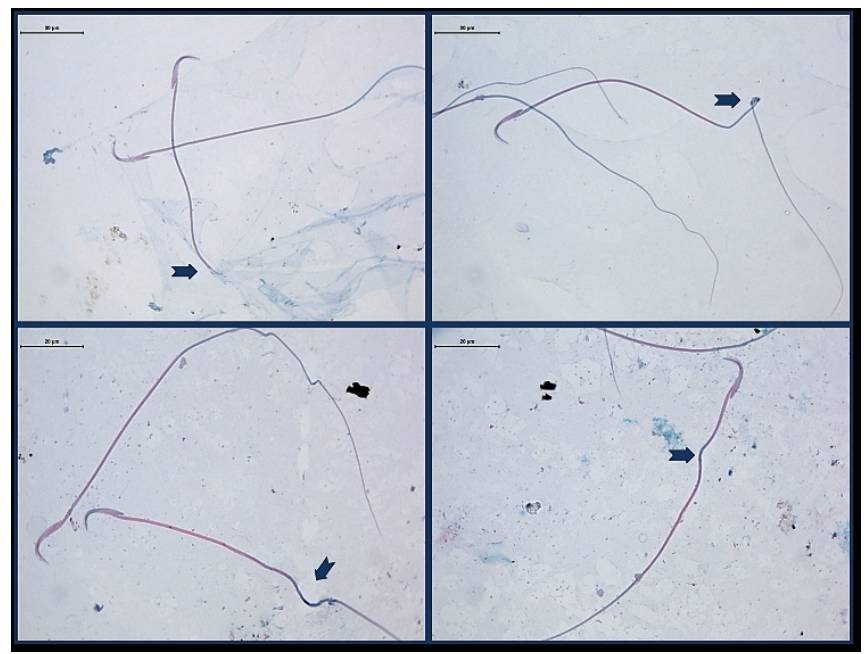

Figure 4. Sperms with tail-structure abnormalities. Tail $(\Rightarrow)$ (Spermac x1000)

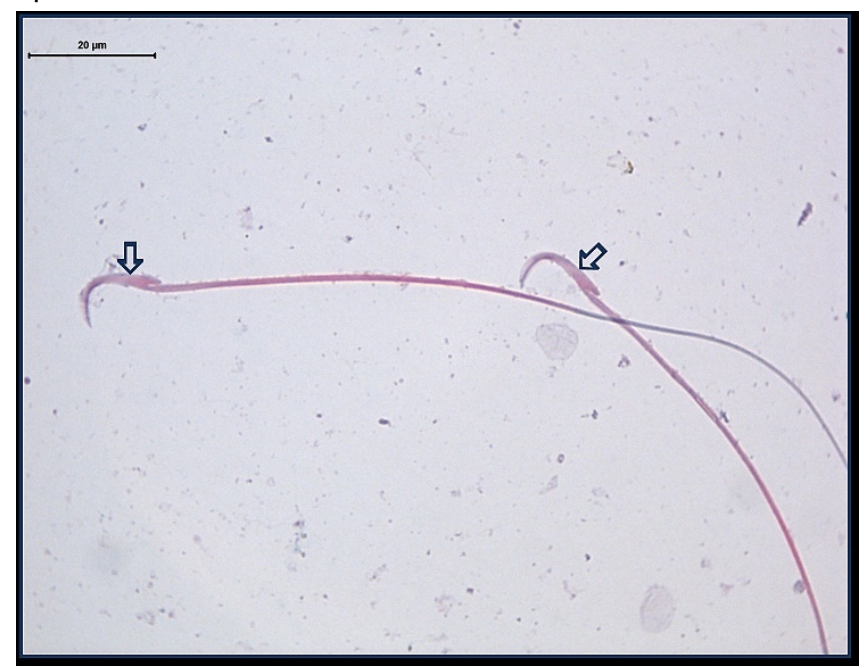

Figure 5. Sperms with acrosome abnormalities. Acrosome $(\Rightarrow)$ (Spermac x1000)

usually observed in the form of a complete elimination of the acrosome, while some of the acrosome showed weak structure in the away region of the neck in sperms (Figure 5). In some sperms, cytoplasmic droplets were seen 


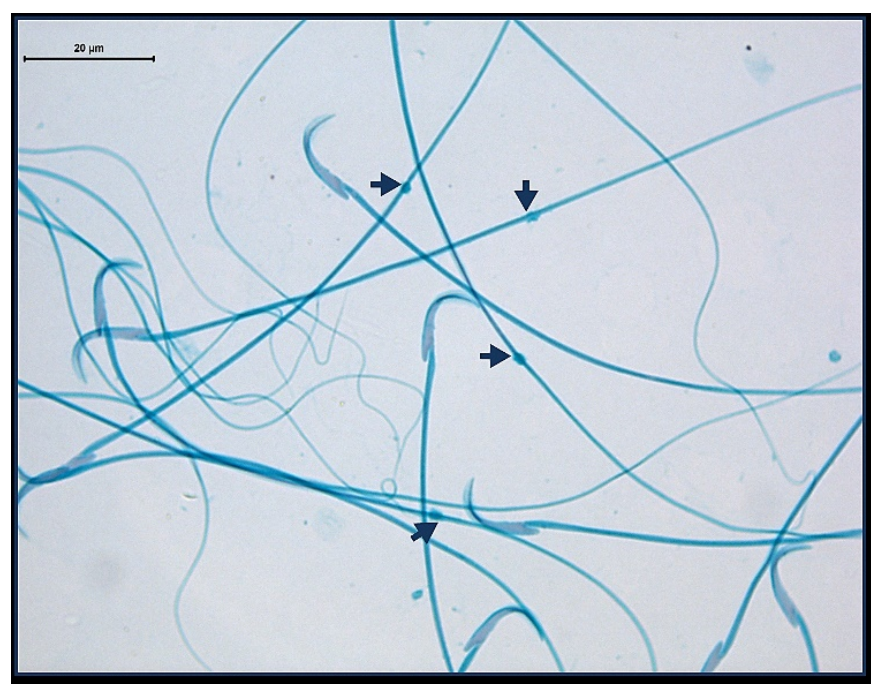

Figure 6. Sperms with cytoplasmic droplet $(\rightarrow)($ Spermac x1000)

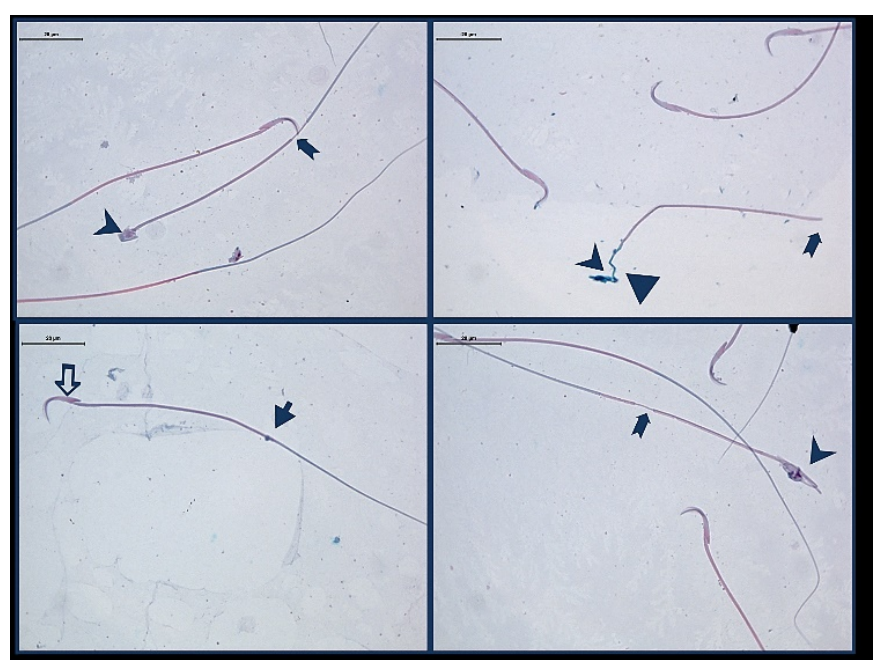

Figure 7. Sperms with multiple abnormalities. Head (>), acrosome $(\Rightarrow)$, neck $(\rightarrow)$, tail $(\Rightarrow)$ and cytoplasmic droplet $(\rightarrow)$ (Spermac x1000)

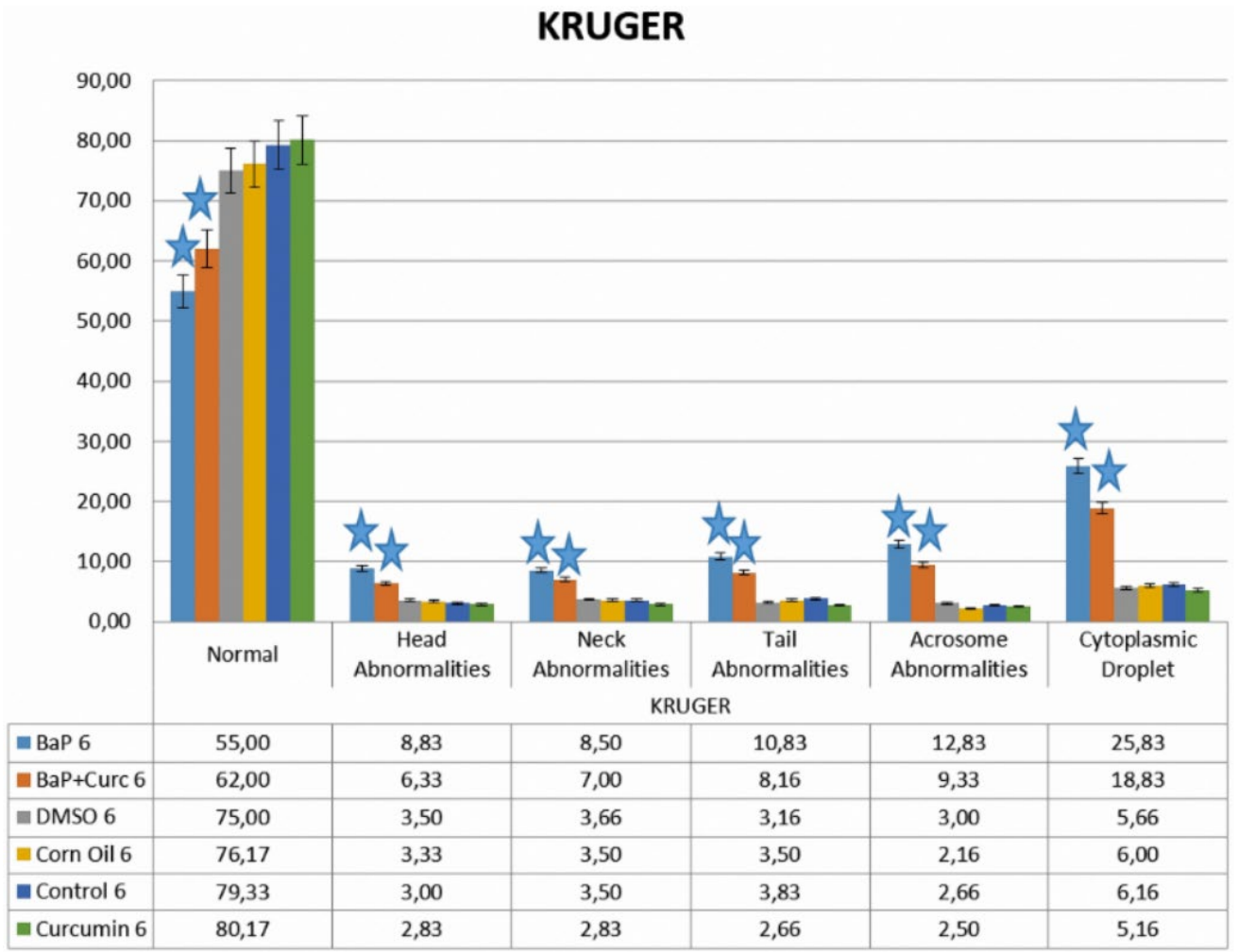

Graphic 1. The descriptive statistics with the error bars of normal and abnormal sperm numbers between the groups

in different parts of the tail (Figure 6). In some areas, some sperms were seen with multiple abnormalities (Figure 7).

By statistical evaluation according to groups it was concluded that the number of normal sperms decreased by BaP administration. In addition, the number of normal sperms were similar in the control, corn oil, DMSO and curcumin administration groups. Head, neck, tail and acrosome abnormalities increased by $\mathrm{BaP}$ administration and it was noted that acrosome abnormalities and cytoplasmic droplets were the most commonly seen abnormalities by BaP administration through the sperms. In the $\mathrm{BaP}+\mathrm{Curcumin}$ administration group it was observed that the number of normal sperms increased while the number of sperms with abnormalities decreased (Graphic 1).

\section{ARC Measurement Results}

By statistical evaluation of the perinuclear ring of the manchette and the posterior portion of the nucleus measurement (ARC) it was observed that the angular distance increased by BaP administration. The angular rate 


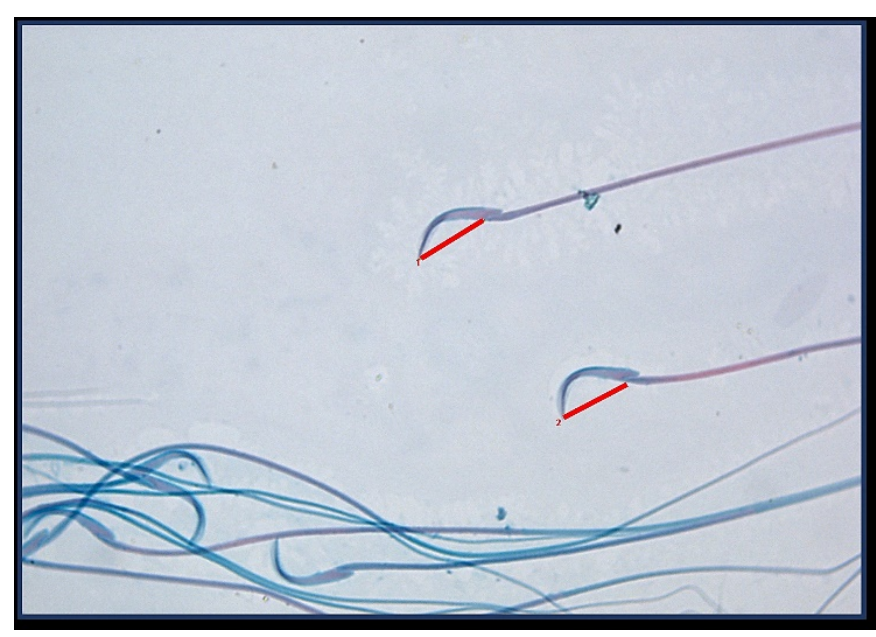

Figure 8. Perinuclear ring of the manchette and the posterior portion of the nucleus (ARC) measurement
ARC Measurement

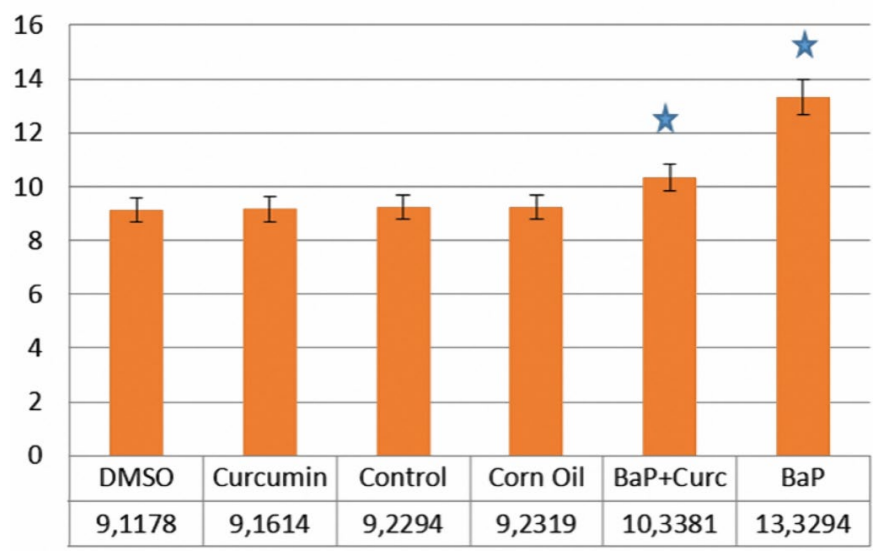

Graphic 2. The descriptive statistics with the error bars of perinuclear ring of the manchette and the posterior portion of the nucleus (ARC) measurement between the groups

\section{Sperm Count}

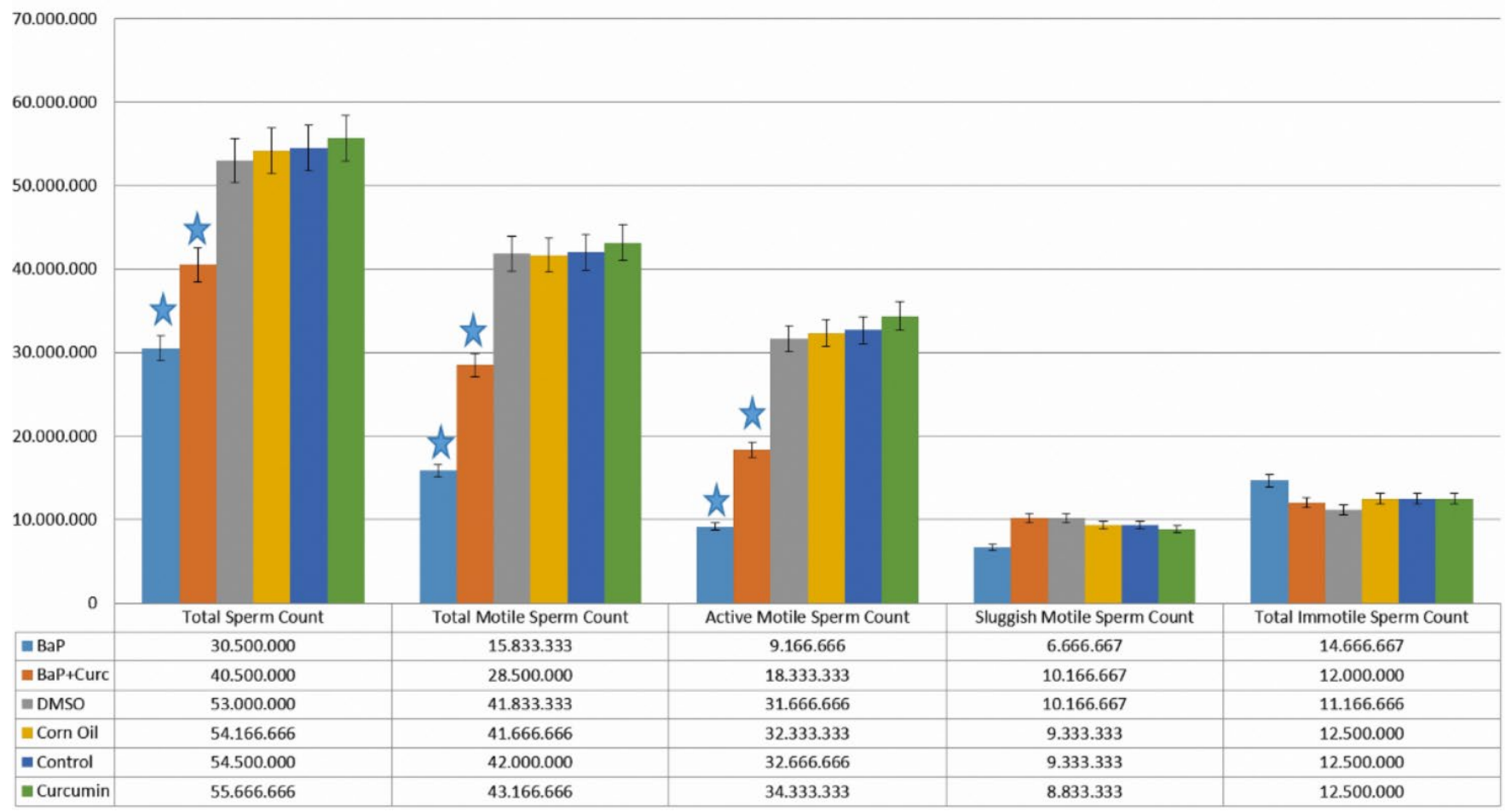

Graphic 3. The descriptive statistics with the error bars of spermiogram results between the groups

was similar in the control, corn oil, DMSO and curcumin groups. In the $\mathrm{BaP}+$ Curcumin group it was established that curcumin brought the rate of sperms closer to the control group ( $p<0.05$ ) (Figure 8 and Graphic 2).

\section{Spermiogram Results}

The number of total sperms, total motile sperms, active motile sperms, sluggish motile sperms and total immotile sperms were counted for all groups and all subjects using a Makler Counting Chamber with the variables being analyzed statistically. According to the data obtained, the total number of sperms, total motile sperm and active motile sperm decreased by BaP administration. In the control, corn oil, DMSO and curcumin groups, no significiant difference was observed statistically. In the $\mathrm{BaP}+$ Curcumin administration group, the total number of sperms, total motile sperm and active motile sperm increased (Graphic 3).

\section{DISCUSSION}

The present study is designed to determine the possible adverse effects of $\mathrm{BaP}$ and the possible protective effects of curcumin as an antioxidant on male fertility after direct exposure through rats. To determine the effects of BaP and 
also curcumin on reproduction, we focus on morphological examinations of sperm and spermiogram.

$\mathrm{BaP}$ induced testicular malformation, decreased sperm motility with $10 \mathrm{mg} / \mathrm{kg}$ (high dose) oral administrations over six weeks, so Mohamed et al. conclude that exposure to $\mathrm{BaP}$ at high doses decreases the fertilization potential through mice in subsequent generations and has an adverse effect on sperm function and fertility [10]. Similarly, Reddy et al. found in their study that $100 \mu \mathrm{g} / \mathrm{kg} \mathrm{BaP}$ administration causes testicular and epididymal toxicity, endangers male reproduction by affecting spermatogenesis, and steroidogenesis, by inducing oxidative toxicity in testis and epididymis, and by reducing fertility efficiency through rats [22]. Another study in this field also shows that long-term exposure to low concentrations of $\mathrm{BaP}$ might disrupt testosterone production in Leydig cells via an alteration of steroidogenic proteins and also decrease epididymal sperm quality by disturbing testosterone levels via Leydig cells [11]. Banerjee et al. investigated the effects of five $\mathrm{mg} / \mathrm{kg} B a P$ for 60 days through rats and found that $\mathrm{BaP}$ exposure decreases the epididymal sperm count and motility, diminishes serum testosterone level and induces apoptosis in testis. Researchers also examined the protective effects of $50 \mathrm{mg} /$ $\mathrm{kg}$ resveratrol as an antioxidant against these destructions, and came to the conclusion that resveratrol could be a new hope as a potential protector of reproductive health against $\mathrm{BaP}[1]$.

Supporting the literature, the number of normal sperms decreased by BaP administration according to our study, with head, neck, tail and acrosome abnormalities increasing through $\mathrm{BaP}$ administration, and it was determined that acrosome abnormalities and the cytoplasmic droplets are the most commonly noted abnormalities with BaP administration. In addition, it was seen that the number of total sperm, total motile sperm and active motile sperm decreases with $\mathrm{BaP}$ administration.

Dose-response modelling was studied by O'Brien et al. administering $\mathrm{BaP}$ in different doses (from 12.5 to $100 \mathrm{mg}$ / $\mathrm{kg} /$ day) for 28 days by gavage to male mice. After this, they collected germ cells from the cauda epididymis and seminiferous tubules. As a result, they demonstrated that oral exposure to $\mathrm{BaP}$ causes spermatogonial stem cell mutations, in different phases (post-spermatogonia, dividing spermatogonia, and spermatogonial stem cells) of spermatogenesis [23]. Another study also demonstrated that $\mathrm{BaP}$ exposure during fetal development increases mutation in the soma and sperm of adult mice [24].
The transformation of spermatids into functional sperm is extremely important during mammalian spermiogenesis involving the shaping and condensation of the nucleus and the formation of the acrosome and tail [25]. Additionally, microtubules are critical components of cells. Control of microtubule length, number, and movement is essential for many cellular processes, so mutation is associated with defects in microtubule structures involved in the division of immature sperm cells, in structures that shape the sperm head and the sperm tail which is essential for sperm movement in the female reproductive tract. Nucleation of microtubules in the manchette is thought to arise in the perinuclear ring region of the spermatid head, so while examining head abnormalities through mutants, abnormal manchette structure or function is important. For instance, elongating spermatids display several abnormalities, including perinuclear rings [26]. In line with this, fractionated manchette perinuclear rings of various diameters have been demonstrated [25], so the distance between the perinuclear ring of the manchette and the posterior portion of the nucleus is important for the determination of deformation in the nucleus [26].

The distance between the perinuclear ring of the manchette and the posterior portion of the nucleus (ARC) is measured in our study and it can be seen that the angular distance increases with $\mathrm{BaP}$ administration, and that curcumin brings closer the rate of sperms to the control group.

Curcumin, used for thousands of years in natural medicine, is now considered to be a potentially therapeutic drug in clinical practice. Until now, few studies have been published on the possible protective or therapeutic effects of curcumin on fertility $[21,27]$. The action of curcumin on semen quality parameters as an antioxidant in different toxic condition was investigated by Glombik et al. who found that the antiinflammatory and anti-oxidant effects of curcumin were dependent on its concentration. In summary, curcumin has a protective effect against any toxic condition of the male reproductive system, but high concentrations also have a cytotoxic on male reproductive cells in vitro [15].

According to examinations based on semen parameters in toxic or destructive conditions, such as varicocele [14] and cyclophosphamide [28] models, it has been determined that curcumin administration can decrease NO levels and improve sperm parameters [14], amplify sperm count, motility and viability, especially when used with zinc and can reverse adverse effects of arsenite on sperm parameters [28].

The number of normal sperms increased while the number of sperms with abnormalities decreased with Curcumin 
administration against BaP according to our study. Additionally, the number of total sperm, total motile sperm and active motile sperm increased in the $\mathrm{BaP}+$ Curcumin administration group.

Unlike other studies, Naz found in his research that curcumin causes intracellular acidification and membrane hyperpolarization thereby inhibiting sperm forward motility through healthy and fertile men when sperm samples were incubated at various concentrations (50 - $400 \mu \mathrm{M})$ of curcumin [16].

Soleimanzadeh and Saberivand examined the antioxidant properties of curcumin against oxidative stress in the cryopreservation process. It is known that cryopreservation induces reactive oxygen species generation and is responsible for sperm damage. According to this study, when sperm samples are supplemented with $2.5 \mathrm{mM}$ curcumin in a freezing process, it can be concluded that curcumin addition during freezing results in positive effects on sperm parameters after thawing through adult rats [29]. Similarly, Zhang et al. Showed that curcumin can significiantly improve sperm motility against oxidative damage induced by the $\mathrm{H}_{2} \mathrm{O}_{2}$ of leucocytospermic patients [30].

Although there are few studies that describe the relationship between $\mathrm{BaP}$, curcumin and male reproduction, a study published in 2016 shows that curcumin modulated MAPKs and p53 prevents oxidative stress, regulates the expression of pro and anti apoptotic proteins so protecting male germ cells from BaP induced apoptosis, especially when used with resveratrol by creating a synergistical effect. In addition, it was determined in this study that $50 \mathrm{mg}$ curcumin and resveratrol prevents germ cell apoptosis in BaP administrations, but increasing the dose does not show any further improvement in their functions [2].

\section{CONCLUSION}

Taken together, curcumin is one of the antioxidant that could be used potentially to inhibit the detrimental effects of benzo(a)pyrene on semen parameters, but it is not sufficient to prevent all abnormalities.

This is the first study based on the effects of curcumin applications on semen parameters of rats in $\mathrm{BaP}$ administration, so we are of the opinion that future studies should be based on using combined antioxidants with curcumin which can provide more descriptive results regarding this research.

\section{ACKNOWLEDGEMENTS}

We would like to thank Mr. Edward McQuaid English Lecturer at Anadolu University (Editing). Also, this study was presented at ASRM, Baltimore, Maryland, 17-21 October, 2015, as a poster presentation, with the abstract being published in Fertility and Sterility, Vol.104, No.35. We certify that there is no conflict of interest with any financial organization regarding the material discussed in the manuscript.

\section{DECLARATION OF CONFLICT OF INTEREST}

The authors received no financial support for the research and/or authorship of this article. There is no conflict of interest.

\section{REFERENCES}

1. Banerjee B, Nandi P, Chakraborty S, Raha S, Sen PC, Jana K. Resveratrol ameliorates benzo(a)pyrene-induced testicular dysfunction and apoptosis: Involvement of p38 MAPK/ATF2/iNOS signaling. Journal of Nutritional Biochemistry 2016; 34: 17-29. (doi: 10.1016/j.jnutbio.2016.04.003).

2. Banerjee B, Chakraborty S, Ghosh D, Raha S, Sen PC, Jana K. Benzo(a)pyrene induced p53 mediated male germ cell apoptosis: Synergistic protective effects of curcumin and resveratrol. Frontiers in Pharmacology 2016; 7(245): 1-20. (doi: 10.3389/fphar.2016.00245).

3. Godschalk RW, Verhofstad N, Verheije $M$, Yauk CL, Linschooten J, Steeg $\mathrm{H}$, Oostrom CT, Bnethem J, Schooten FJ. Effects of benzo[a]pyrene on Mouse germ cells: Heritable DNA mutation, testicular cell hypomethylation and their interaction with nucleotide excision repair. Toxicolocigal Research 2015; 4: 718-24. (doi: 10.1039/C4TX00114A).

4. Verhofstad N, Oostrom CT, Zwart E, Maas LM, Benthem J, Schooten FJ, Steeg H, Godschalk RWL. Evaluation of Benzo(a)pyrene-induced gene mutations in male germ cells. Toxicological Sciences 2011; 119(1): 218-23. (doi: 10.1093/toxsci/kfq325).

5. Kim KH, Jahan SA, Kabir E, Brown RJC. A review of airbone polycyclic hydrocarbons (PAHs) and their human health effects. Environment International 2013; 60: 71-80. (doi: 10.1016/j.envint.2013.07.019). 
6. Borman SM, Christian PJ, Sipes IG, Hoyer PB. Ovotoxicity in female Fischer rats and B6 mice induced by low-dose exposure to three polycyclic aromatic hydrocarbons: comparison through calculation of an ovotoxic index. Toxicology and Applied Pharmacology 2000; 167: 191-8. (doi: 10.1006/taap.2000.9006).

7. Yauk CL, Quinn JS. Multilocus DNA fingerprinting reveals high rate of heritable genetic mutation in herring gulls nesting in an industrialized urban site. PNA1996; 93(22): 12137-41. (doi: 10.1073/pnas.93.22.12137).

8. Inyang F, Ramesh A, Kopsombut P, Niaz MS, Hood DB, Nyanda AM, Archibong AE. Disruption of testicular steroidogenesis and epididymal function by inhaled benzo(a)pyrene. Reproductive Toxicology 2003; 17: 527 37. (doi: 10.1016/S0890-6238(03)00071-6).

9. Moffat I, Chepelev NL, Labib S, Bourdon-Lacombe J, Kuo B, Buick JK, Lemieux F, Williams A, et al. Comparison of toxicogenomics and traditional approaches to inform mode of action and points of departure in human health risk assessment of benzo[a]pyrene in drinking water. Critical Reviews in Toxicology 2015; 8444: 1-43. (doi: 10.3109/10408444.2014.973934).

10. Mohamed EA, Song WH, Oh SA, Park YJ, You YA, Lee S, Choi JY, et al. The transgenerational impact of benzo(a)pyrene on murine male fertility. Human Reproduction 2010; 25(10): 2427-33. (doi: 10.1093/humrep/deq205).

11. Chung JY, Kim YJ, Kim JY, Lee SG, Park JE, Kim WR, Yoon YD, Yoo KS, Yoo YH, Kim JM. Benzo[a]pyrene reduces testosterone production in rat Leydig cells via direct disturbance of testicular steroidogenic machinery. Environmental Health Perspectives 2011; 119: 1569-74. (doi: 10.1289/ehp.1003391).

12. Sheweita SA, Al-Shora S, Hassan M. Effects of benzo[a]pyrene as an environmental pollutant and two natural antioxidants on biomarkers of reproductive dysfunction in male rats. Environmental Science and Pollution Research 2016; 23: 17226-35. (doi: 10.1007/s11356-016-6934-4).

13. Georgellis A, Parvinen M, Rydström J. Inhibition of stagespecific DNA synthesis in rat spermatogenic cells by polycyclic aromatic hydrocarbons. Chemico-Biological Interactions 1989; 72(1): 79-92.
14. Izadpanah $M$, Alizadeh $R$, Minaee MB, Heydari $L$, Babatunde A, Abbasi M. The effects of curcumin on sperm parameters and nitric oxide production in varicocelized rats. International Journal of Morphology 2015; 33(4): 1530-1535. (doi: 10.4067/S071795022015000400055).

15. Glombik K, Basta-Kaim A, Sikora-Polaczek M, Kubera M, Starowicz G, Styrna J. Curcumin influences semen quality parameters and reverses the di(2-ethylhexyl)phthalate (DEHP)-induved testicular damage in mice. Pharmacological Reports 2014; 66: 782-7. (doi: 10.1016/j.pharep.2014.04.010).

16. Naz RK. The effect of curcumin on intracellular $\mathrm{pH}(\mathrm{pHi})$, membrane hyperpolarization and sperm motility. Journal of Reproduction \& Infertility 2014; 15(2): 62-70.

17. Naz RK. Can curcumin provide an ideal contraceptive? Molecular Reproduction and Development 2011; 78(2):116-23. (doi: 10.1002/mrd.21276).

18. Momeni HR, Eskandari N. Curcumin inhibits the adverse effects of sodium arsenite in Mouse epididymal sperm. International Journal of Fertility \& Sterility 2016; 10(2): 245-52.

19. Gupta SC, Patchva S, Aggarwa BB. Therapeutic roles of curcumin: Lessons learned from clinical trials. AAPS Journal 2013; 15(1): 195-218. (doi: 10.1208/s12248-0129432-8).

20. Sahoo DK, Roy A, Chainy GB. Protective effects of vitamin $E$ and curcumin on L-thyroxine-induced rat testicular oxidative stress. Chemico-Biological Interactions 2008; 176(2-3): 121-8. (doi: 10.1016/j.cbi.2008.07.009).

21. Oguzturk H, Ciftci O, Aydın M, Timurkaan N, Beytur A, Yılmaz F. Ameliorative effects of curcumin against acute cadmium toxicity on male reproductive system in rats. Andrologia 2012; 44(4): 243-9. (doi: 10.1111/j.14390272.2012.01273.x).

22. Reddy KP, Reddy PS. Testicular and epididymal toxicity induced by benzo(a)pyrene, alcohol, and their combination in Wistar rats. Toxicological Research 2016; 5: 420-33. (doi: 10.1039/c5tx00420a).

23. O'Brien JM, Beal MA, Yauk CL, Marchetti $F$. Benzo(a)pyrene is mutageniz in Mouse spermatogonial stem cells and dividing spermatogonia. Toxicological Sciences 2016; 152(2): 363-71. (doi: 10.1093/toxsci/kfw088). 
24. Meier MJ, O'Brien JM, Beal MA, Allan, B Yauk CL, Marchetti F. In utero exposure to Benzo[a]pyrene increases mutation burden in the soma and sperm of adult mice. Environmental Health Perspectives 2017; 125(1): 82-8. (doi: 10.1289/EHP211).

25. Mochida K, Tres LL, Kierszenbaum AL. Isolation of the rat spermatid manchette and its perinuclear ring. Developmental Biology 1998; 200: 46-56. (doi: 10.1006/dbio.1998.8942).

26. O'Donnell L, Rhodes D, Smith SJ, Merriner DJ, Clark BJ, et al. An essential role for katanin p80 and microtubule severing in male gamete production. PLoS Genetics 2012; 8(5): 1-12. (doi: 10.1371/journal.pgen.1002698).

27. Khorsandi L, Mirhoseini M, Mohamadpour M, Orazizadeh M, Khaghani S. Effect of curcumin on dexamethasoneinduced testicular toxicity in mice. Pharmaceutical Biology 2013; 51(2): 06-212. (doi: 10.3109/13880209.2012.716854).
28. Lu WP, Mei XT, Wang Y, Zheng YP, Xue Y, Xu DH. Zn (II)curcumin protects against oxidative stress, deleterious changes in sperm parameters and histological alterations in a male mouse model of cyclophosphamide-induced reproductive damage. Environmental Toxicology and Pharmacology 2015; 39: 515-24. (doi: 10.1016/j.etap.2014.12.014).

29. Soleimanzadeh A, Saberivand A. Effect of curcumin on rat sperm morphology after the freze-thawing process. Veterinary Research Forum 2013; 4(3): 185-9.

30. Zhang L, Diao RY, Duan YG, Yi TH, Cai ZM. In vitro antioxidant effect of curcumin on human sperm quality in leucocytospermia. Andrologia 2017; 49(10): 1-6. (doi: 10.1111/and.12760). 